\title{
Archeological Investigations at the Harrison Bayou Site (41HS240) in Harrison County, Texas
}

Timothy K. Perttula

Heritage Research Center, Stephen F. Austin State University

Bo Nelson

Heritage Research Center, Stephen F. Austin State University

Follow this and additional works at: https://scholarworks.sfasu.edu/ita

Part of the American Material Culture Commons, Archaeological Anthropology Commons, Environmental Studies Commons, Other American Studies Commons, Other Arts and Humanities Commons, Other History of Art, Architecture, and Archaeology Commons, and the United States History Commons

Tell us how this article helped you.

This Article is brought to you for free and open access by the Center for Regional Heritage Research at SFA ScholarWorks. It has been accepted for inclusion in Index of Texas Archaeology: Open Access Gray Literature from the Lone Star State by an authorized editor of SFA ScholarWorks. For more information, please contact cdsscholarworks@sfasu.edu. 


\section{Archeological Investigations at the Harrison Bayou Site (41HS240) in Harrison County, Texas}

\section{Creative Commons License}

\section{(c) (1) (8)}

This work is licensed under a Creative Commons Attribution-NonCommercial 4.0 International License 


\title{
Archeological Investigations at the Harrison Bayou Site (41HS240) in Harrison County, Texas
}

\author{
Timothy K. Perttula and Bo Nelson
}

\begin{abstract}
Introduction
We recently completed archeological investigations on approximately 1400 acres of land on Harrison Bayou, Longhorn Army Ammunition Plant, Harrison County, Texas, leased by the Caddo Lake Institute, Inc. (Perttula and Nelson 1999). The Caddo Lake Institute, Inc. leased this portion of the Longhorn Army Ammunition Plant (LHAAP) for 30 years under a September 1996 Memorandum of Agreement (MOA) with the Department of the Army. These archeological investigations were completed under Archeological Resources Protection Permit DACA63-497-0580 issued September 1, 1997, by the Real Estate Division of the Department of

the Army, Fort Worth District, Corps of Engineers to the Caddo Lake Institute, Inc.

During these investigations, intensive shovel testing and a limited amount of hand excavations were completed at the Harrison Bayou site (41HS240), one of the earliest reported Caddoan sites in Northeast Texas (Ford 1936), but still one of the more poorly known sites in the region. In this paper, we discuss the work we conducted at the Harrison Bayou site, and summarize the archeological findings from this important Middle Caddoan period occupation at Caddo Lake.
\end{abstract}

\section{Environmental Setting}

The Caddo lake bioregion is in the Western Gulf Coastal Plain, in the Big Cypress Bayou basin of Northeast Texas and northwestern Louisiana. The Caddo Lake watershed includes all of Camp and Marion counties, and portions of Cass, Franklin, Gregg, Harrison, Hopkins, Morris, Titus, Upshur, and Wood counties, in Northeast Texas, and parts of Caddo Parish in northwestern Louisiana.
This is an area of more than 2350 square miles. The modern climate is humid subtropical, with warm summers and mild winters, with 43 - 50 inches of precipitation a year, principally falling in the spring and winter. The average growing season is more than 240 days (Ingold and Hardy 1996).

While now mainly second growth pines 
Volume 11(3), October 2000

more than 240 days (Ingold and Hardy 1996).

While now mainly second growth pines and hardwoods, this general region was an area of mixed oak woodlands and mixed pine-hardwood forests (Brown et al 1998; Diamond et al. 1987) referred to as the Pineywoods or the Southeastern Deciduous and Evergreen Forest, with hardwoods, cypress, tupelo, and sweetgum in bottomland riverine, marsh, and swamp habitats (Hardy 1995; Ingold 1995; Ingold and Hardy 1996; Sheffield 1995). The unique habitats around Caddo Lake, a natural lake formed in the late 1700 s due to flooding and natural levee breaks along the Red River caused by the Great Raft and increased water levels along distributary channels (Pearson et al. 1994), includes cypress swamps, marshes, grasslands, bottomland hardwood forests (particularly along Harrison Bayou), and pine forests.

Caddo Lake at its maximum extent may have reached elevations (although fluctuating) between 173 and 180 feet, based on historic maps, studies of lacustrine deposits on the lake bed, and relict shorelines (U.S. Department of the Interior 1914; Albertson and Dunbar 1993). Albertson and Dunbar (1993:41) characterize Caddo Lake as "a shallow, 3- to 5mile-wide (4.83- to $8.05-\mathrm{km})$, drainage basin lake with a narrow valley at its confluence to the Red River. The entrance into Caddo Lake from Twelvemile Bayou is a natural setting for the location of Caddo Dam [constructed in 1914], since the valley is so narrow at this location ... formation of Caddo Lake would have flooded the existing floodplain of Big Cypress Bayou."

The Harrison Bayou lease lands are comprised of alluvial bottomlands along Harrison Bayou, a major tributary to Caddo Lake and Big Cypress Bayou, Martin's Bayou, and Saunders Branch, a small area of upland flats between Goose Prairie and Martin's Bayou, and eroded uplands across the remainder of the 1400 acre lease area (environmental/topographic zones follow Cliff et al. [1996:Figure E1]). The lease lands range between 168 and 200 feet amsl, and are generally characterized by shallow sandy loam sediments in upland settings (Golden et al. 1994; Van Duyne and Byers 1913), silt loam alluvial sediments, and sandy loam natural mounds in certain floodplain settings along Harrison Bayou.

At its estimated water level of 173.09 feet amsl in historic times, the waters of Caddo Lake in the Harrison Bayou lease lands would have inundated Rag Island, and extended at least $0.5-2 \mathrm{~km}$ up Martin's Bayou, Saunders Branch, and Harrison Bayou, respectively. A lacustrine delta and point bar deposits probably began to form above the Harrison Bayou embayment with the formation of Caddo Lake, and these deposits are marked by distinctive mounded alluvial deposits (i.e., pimple mounds) and deep sandy loam sediments of the Metcalf-Cart and Guyton-Cart complexes (Albertson and Dunbar 1993; Golden et al. 1994). This embayment area is just to the north of the Harrison Bayou site. 


\section{Archeological Investigations at the Harrison Bayou Site (41HS240) at Caddo Lake}

The Harrison Bayou site has been of archeological interest since the early 1930 s, and has been the subject of several studies and archeological survey investigations from the 1930 s to the present time (Ford 1936; Webb 1948; Gibson 1970; Peter and Stiles-Hanson 1990; Cliff et al. 1995; Cliff et al. 1996; Gadus et al. 1998). The 1998 Caddo Lake Institute, Inc. archeological investigations at the Harrison Bayou site, however, are the first to systematically examine the entire site area and gather comprehensive information on the extent and depth of the archeological deposits, the density of archeological materials, and the potential for the site to contain features and/or midden deposits.

The Harrison Bayou site is situated on a prominent upland ridge (180 feet amsl) overlooking the Harrison Bayou floodplain and the current channel of the bayou is about 100 meters to the west (Figure 1). The ridge is primarily covered in pines and hardwoods, with a surface visibility of less than five percent except along two dirt two-track roads, and in the far northwestern part of the site, where early 1990s bulldozing (Cliff et al. 1995; Gadus et al. 1998) had created an open grassy area. The ridge has Eastwood very

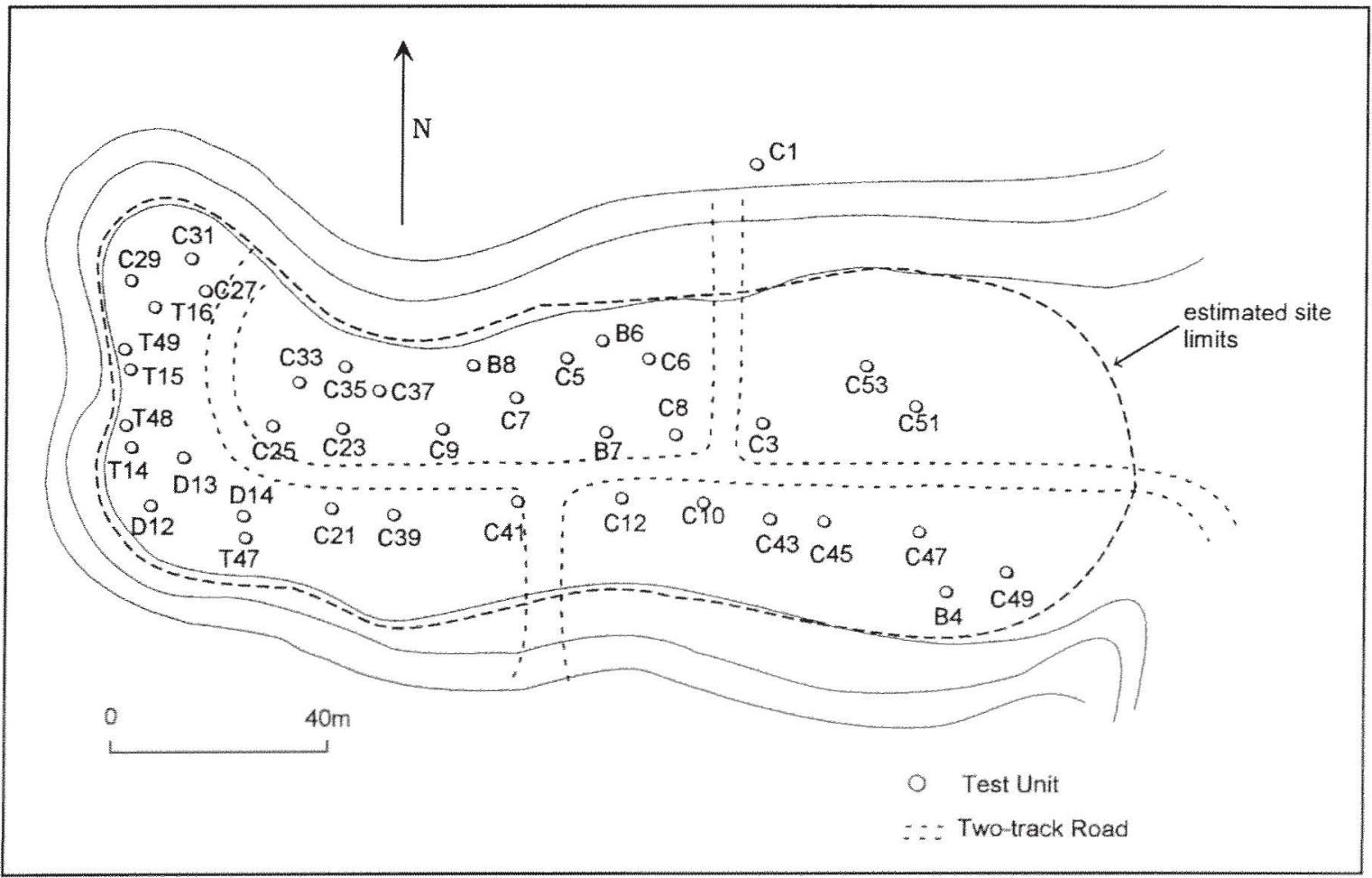

Figure 1. Map of the Harrison Bayou site (41HS240). 
fine sandy loam sediments, with $40-80$ $\mathrm{cm}$ of sandy loam overlying a B-horizon clay.

Gadus et al. (1998) provide the most recent summary of the history of archeological investigations at the Harrison Bayou site. Ford's (1936) and Webb's (1948) analyses of ceramic sherd collections from the site indicated that the site was occupied by Caddoan groups during Early, Middle (Bossier phase), and Late Caddoan times, and the presence of a variety of dart points, stone gorgets, beads, and boatstones (Ford 1936:Figure 15) also suggested the site had been used during late Paleoindian, Middle Archaic, and Late Archaic times (see also Gibson 1970). Gibson's (1970) investigations indicated that the site contained as much as $70 \mathrm{~cm}$ of cultural midden deposits.

Roemer and Newman (1988) visited the site as part of an archeological assessment of LHAAP test area expansion, and excavated one shovel test that had burned rocks and a ceramic sherd, but they located no midden deposits. They did report that the site had been disturbed by a fire lane, road maintenance, and artifact collecting activities. A later visit in 1988 by Peter and Stiles-Hanson (1990:32) appeared to confirm the findings of Roemer and Newman (1988), in that "limited shovel testing yielded no evidence of a midden and only one Caddoan grog-tempered body sherd ... it is also apparent that the 'midden' area was extremely limited spatially. Further evaluation of the site is needed; however, the present potential of the site for NRHP eligibility is low ....."
In 1993, Geo-Marine, Inc. returned to the Harrison Bayou site (Cliff et al. 1995). During these investigations, they estimated that " 85 percent of the site has had 30 to $60 \mathrm{~cm}$ of topsoil removed, presumably by bulldozer, with the original ground surface being present only along the edges of the terrace" (Cliff et al. 1995:29). Three of the five shovel tests excavated on the upland ridge (all at what is now known to be the western end of the site, see below) contained only a low density of prehistoric and ceramic artifacts (3.0 artifacts per positive shovel test), and no midden deposits were identified over the 0.4 ha (3500 square meters) area. Cliff et al. (1995:37) concluded that the Harrison Bayou site has been extensively disturbed by bulldozing, but that "some subsurface deposits may remain at the base of trees and on the periphery of the bulldozed area ... [but] it is possible that subsoil features .... may remain below the level of disturbance at the site ... it is recommended that the Harrison Bayou site (41HS240) be considered of unknown eligibility for inclusion in the NRHP".

Further investigations by Gadus et al. (1998) in 1997, including an additional six shovel tests in the western part of the Harrison Bayou site, did identify preserved midden deposits between 14 $40 \mathrm{~cm} \mathrm{bs}$ in one shovel test in the southwestern part of the upland ridge (Gadus et al. 1998:Figure 3), with the upper $14 \mathrm{~cm}$ of sediments in that shovel test definitely disturbed by previous bulldozing. No other midden deposits were present within the apparent site boundaries - now estimated at 4300 square meters - and the density of 
prehistoric ceramic and lithic artifacts in two positive shovel tests was 2.50 . They concluded that "no extensive submidden artifact concentrations that might be associated with the early [pre-Caddoan] occupations of the site were encountered ... [but] that submidden soils are undisturbed" (Gadus et al. 1998:28-29). They also supported Cliff et al.'s (1995) finding that the Harrison Bayou site had the potential to contain preserved cultural features.

The Cliff et al. (1995) and Gadus et al. (1998) shovel test investigations together included 11 shovel tests. Only 45 percent of the shovel tests were reported to contain prehistoric archeological materials, with a density of 2.80 artifacts per positive shovel test. The site was estimated to cover between 0.88 and 1.1 acres. The 1998 Caddo Lake Institute, Inc. archeological investigations discussed in this article paint a different picture of the extent and character of the archeological deposits at the Harrison Bayou site. The distribution of shovel tests containing prehistoric lithic and/or ceramic artifacts indicates that the Harrison Bayou site is approximately 8500 square meters (2.1 acres) in size (Figure 1), about twice as large as the earlier work had estimated. Of the 33 shovel tests excavated during the course of the 1998 project, 28 or 85 percent contained prehistoric artifacts, and the density of artifacts in the positive shovel tests is 4.80 artifacts per positive shovel test; this is 70 percent higher in density than the Cliff et al. (1995) and Gadus et al. (1998) work.

During our 1998 investigations, one shovel test (ST T-15) and two $50 \times 50 \mathrm{~cm}$ units in the western part of the site appear to contain preserved midden deposits (marked by a dark brown sandy loam between $23-37 \mathrm{~cm}$ in depth), suggesting that the midden remnants detected by Gadus et al. (1998) are larger than they had previously estimated (Figure 2 ). In ST T-47 and ST T-49, the possible midden deposits began at the surface, while the midden was between $16-37 \mathrm{~cm}$ bs in ST $\mathrm{T}-15$, suggesting that overlying sandy loam deposits have been removed in the former two areas. An additional 35 excavation units were completed during the 1998 work besides the three that may have midden deposits, including 32 shovel tests and three $50 \times 50 \mathrm{~cm}$ units (Figure 1).

A substantial prehistoric archeological assemblage was obtained from the Harrison Bayou site from 28 positive shovel tests and five $50 \times 50 \mathrm{~cm}$ units placed across the site. The assemblage includes 117 pieces of lithic debris, two lithic cores, seven chipped stone tools, one groundstone tool, five fire-cracked rocks, one animal bone, seven pieces of daub and burned clay, and 131 ceramic sherds (Perttula and Nelson 1999:Appendix II, III, VI). The archeological deposits at the Harrison Bayou site are a maximum of 80 $\mathrm{cm}$ in thickness, although more than 94 percent of the artifacts are found from 0 $40 \mathrm{~cm} \mathrm{bs} ; 5.6$ percent of the artifacts are found between $40-60 \mathrm{~cm}$ bs. Within the upper $40 \mathrm{~cm}$ of the sandy loam sediments at the site that contain archeological materials, approximately 59 percent of the artifacts occur between $0-20 \mathrm{~cm}$; both lithic (59.4 percent of the lithic artifacts are in the $0-20 \mathrm{~cm}$ level) and ceramic 


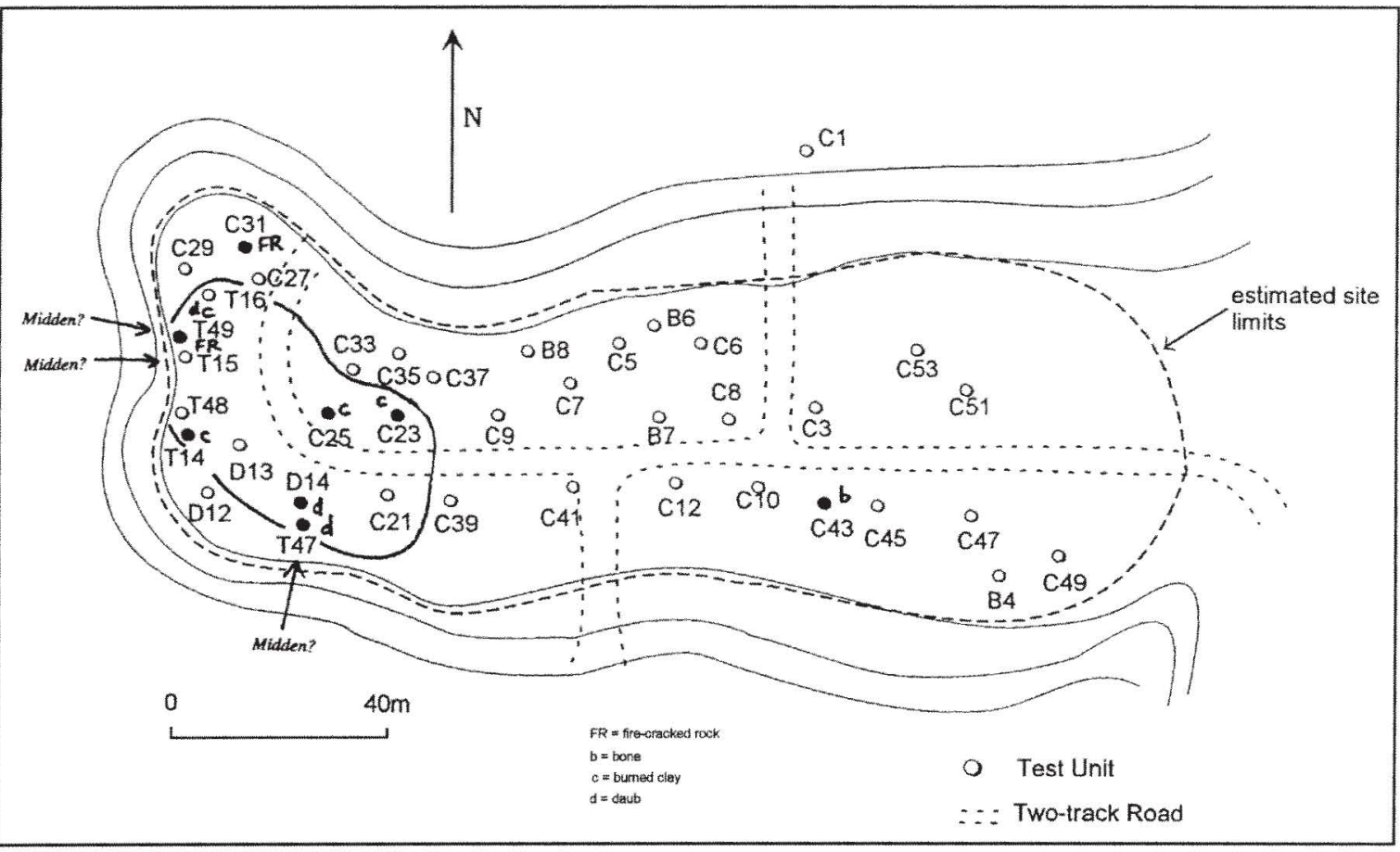

Figure 2. Distribution of bone, daub, burned clay, fire-cracked rock, and shovel tests with preserved midden deposits at the Harrison Bayou site.

(57.5 percent of the ceramic artifacts are in the $0-20 \mathrm{~cm}$ level, including daub and burned clay) artifacts have comparable frequencies within the upper $40 \mathrm{~cm}$, and the single piece of burned animal bone (ST C-43, $0-20 \mathrm{~cm}$; Figure 2) is within the upper $20 \mathrm{~cm}$. The daub, burned clay, and fire-cracked rock are concentrated at the western end of the site, in the same area as the midden deposits (Figure 2).

Lithic debris at Harrison Bayou occurs in densities ranging between $9-192$ artifacts per cubic meter across the site. The highest densities (120 - 192 artifacts per cubic meter) occurred in ST T-47, ST T-48, ST T-49, ST D-12, ST C-12, and ST C-8 at the western and central parts of the ridge landform (Figure 3). The high density of lithic debris at the site's western end is associated with the area of preserved midden deposits, the areas with daub and burned clay, and the large cluster of prehistoric ceramics. The spatial extent of lithic debris at the Harrison Bayou site is about twice as large as the ceramics, and with the exception of three shovel tests (see below), it is accurate to characterize the eastern part of the site as a lithic scatter.

There is a wide diversity in the lithic raw materials represented in the lithic debris from the Harrison Bayou site. In addition to 13 different colors of chert raw materials (principally red, yellow, and brown) that comprise 49.5 percent of the lithic debris, there are Ogallala (fine- 


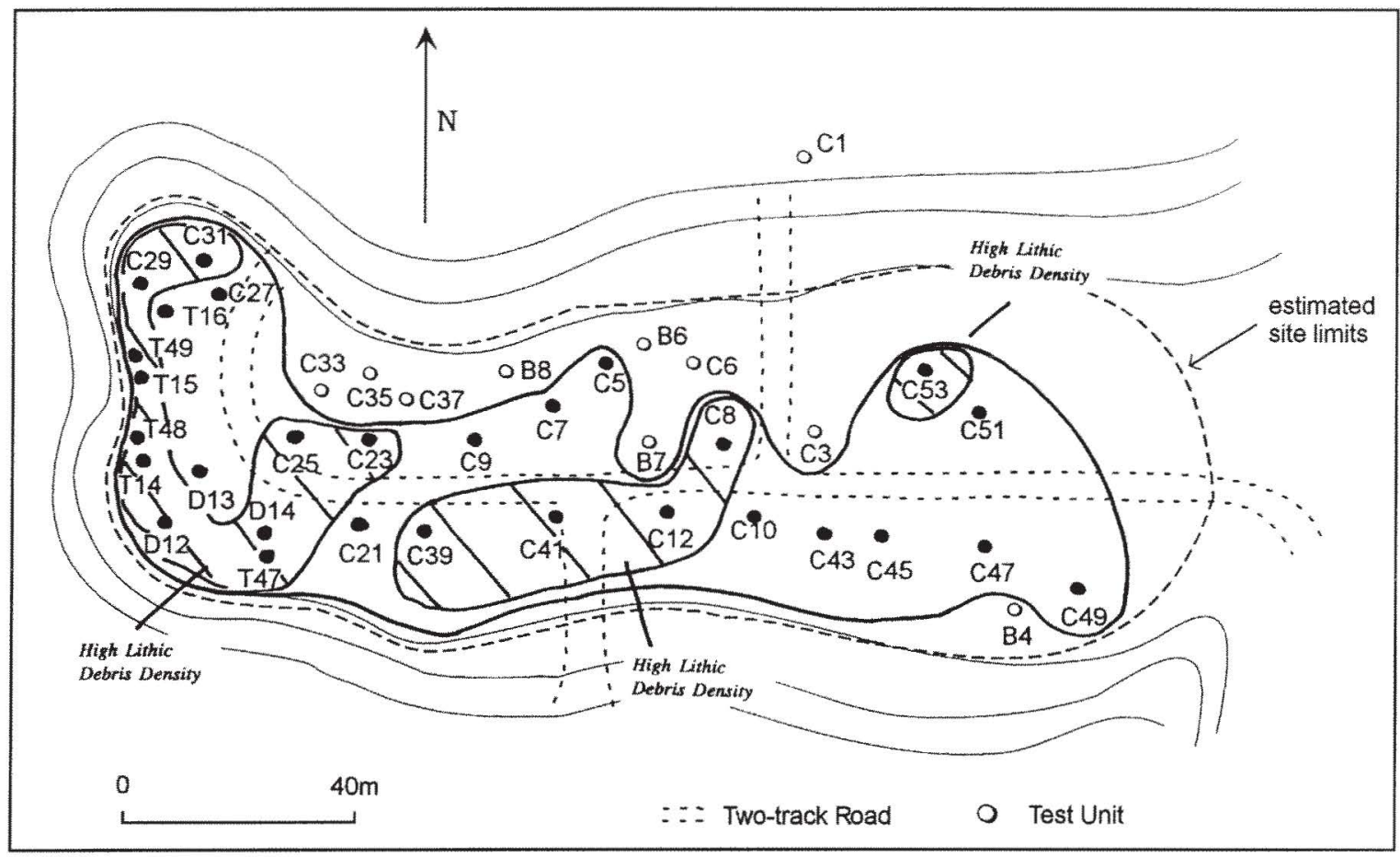

Figure 3. Distribution of lithic debris at the Harrison Bayou site.

grained) and coarse-grained quartzite (2.6 percent), hematite ( 0.9 percent), petrified wood ( 36.8 percent), and novaculite ( 10.3 percent). With the exception of the novaculite and a distinctive black chert, which may represent non-local lithic raw materials, the remainder of the lithic debris appears to be from locally available pebbles and cobbles. More than 55 percent of the lithic debris has cortical remnants (ranging from 33 - 100 percent for the chert, petrified wood, quartzite, and hematite pieces), and one brown chert piece is a bipolar flake; there also is a bipolar core in the lithic assemblage (see below). This evidence in the lithic debris suggests that not only were the great majority of these raw materials available in local gravel sources, but that the initial reduction of these various raw materials (to remove the cortex and obtain flakes or pebble masses for further shaping) for the manufacture of stone tools was a principal focus of the lithic technological activities at Harrison Bayou. Novaculite may be an exception, in that there are no cortical flakes in the Harrison Bayou sample $(\mathrm{n}=$ 12); three pieces of novaculite lithic debris have also been heat-treated. The one hematite flake has a polished outer surface, and may have been knapped from a polished ground-stone axe; hematite was frequently employed in the manufacture of polished and grooved axes during the Late Archaic period in Northeast Texas (Story 1990: Figure 32).

Compared to lithic debris samples from 41HS407 and Starr Ranch (41HS408), also investigated in 1998 in the Harrison 
Volume 11(3), October 2000

Bayou lease lands (Perttula and Nelson 1999), the Harrison Bayou assemblage has a much higher proportion of petrified wood lithic debris (36.8 percent compared to 12.5 - 14.6 percent), and lower percentages of chert (49.5 percent to 53.6 75.0 percent) and novaculite (10.3 percent compared to 12.5 to 19.5 percent). These differences may reflect a diversity in the gravel composition across the Harrison Bayou basin from north (i.e., 41HS407 and Starr Ranch) to south (i.e., the Harrison Bayou site) - or perhaps differences in procurement needs and raw material preferences over time - but additional lithic raw material information from upland and stream gravels would be needed to address this issue, as would other large lithic debris samples from other well-dated prehistoric sites within the Harrison Bayou basin. The very high amounts of petrified wood lithic debris at the Harrison Bayou suggests there may be a source of the raw material in proximity, and it may also indicate that a substantial Late Archaic component is present at the site, since that period was the time when the use of this material for tools appears to have been most common in several locales in Northeast Texas.

A bipolar core and a core fragment were found in ST B-8 $(0-20 \mathrm{~cm})$ and ST T-47 $(0-20 \mathrm{~cm})$, respectively, in the western part of the Harrison Bayou site (Figure 4). The bipolar core was on a local yellowishbrown chert, and measured $25 \times 15 \times 7$ $\mathrm{mm}$ in length, width, and thickness. The

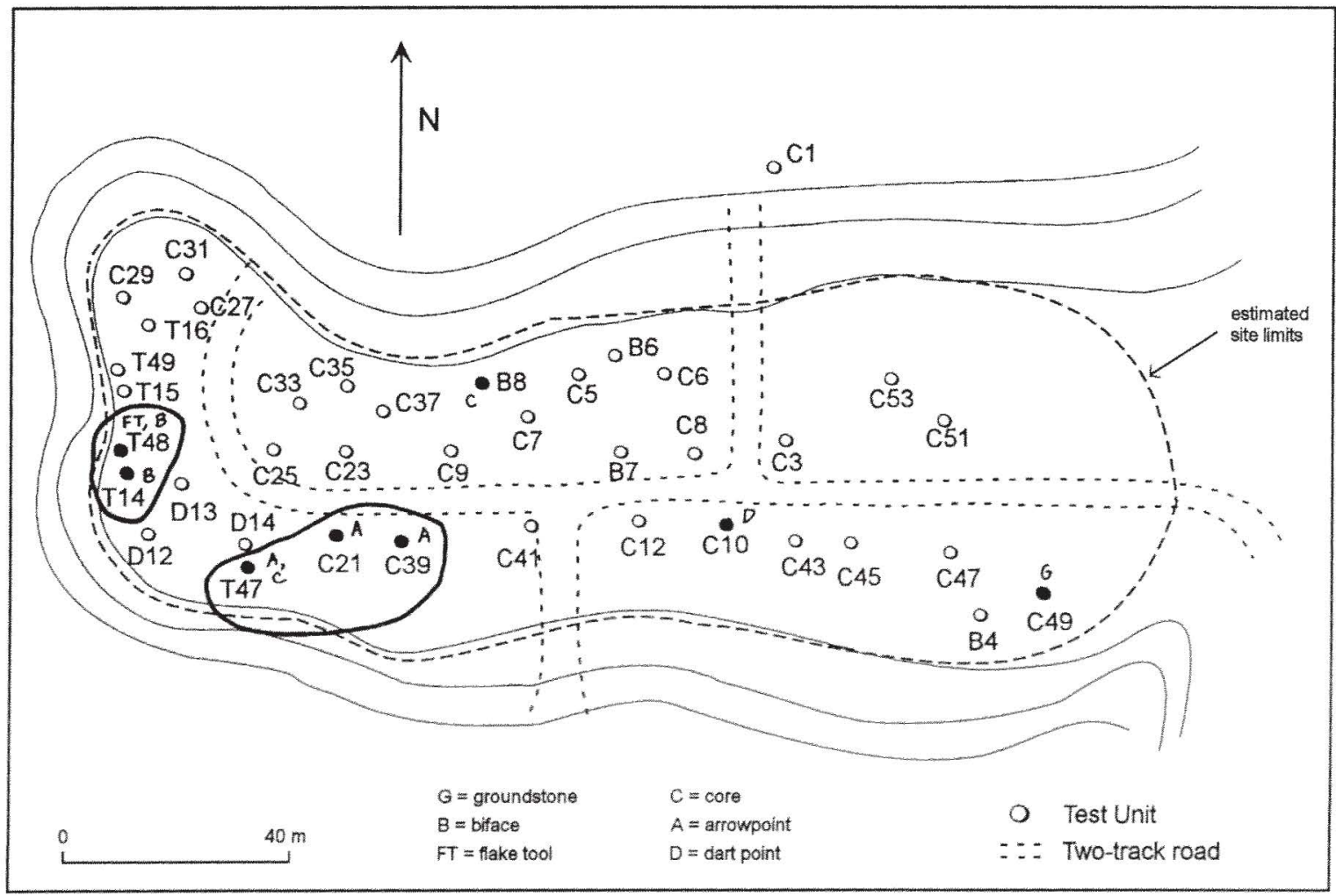

Figure 4. Distribution of lithic tools at the Harrison Bayou site. 
core fragment $(35 \times 10 \times 6 \mathrm{~mm}$ in length, width, and thickness) was on a local red chert.

The seven chipped stone tools from the Harrison Bayou site include three arrowpoints, one dart point, an expedient flake scraping tool, a thin biface, and a bifacial preform. The three chert arrowpoints were from ST C-21 $(0-20$ $\mathrm{cm})$, ST C-39 $(0-24 \mathrm{~cm})$, and ST T-47 (0 $-20 \mathrm{~cm}$ ) in the southwestern part of the site (Figure 4), and at depths associated with the preserved Caddoan midden deposits. The first two have narrow contracting stems and bifacially retouched blades, and range between $16 \mathrm{~mm}$ in length, $10-11 \mathrm{~mm}$ in width, and $2.0-2.4$ $\mathrm{mm}$ in thickness; stem widths are 3.4 and $6.2 \mathrm{~mm}$, respectively. The third is a blade fragment made of a local red chert. The other arrowpoints are made of a local brown chert and a non-local piece of black chert (also heat-pocked from exposure to fire), probably originating in the Red River gravels. These forms of contracting stem arrowpoints are comparable to the Perdiz type, a common arrowpoint type in ca. A.D. 1300 - 1600 Caddoan sites in Northeast Texas.

The dart point is a straight-stemmed fragment, probably of Late Archaic or Woodland period age, from ST C-10 (0 $20 \mathrm{~cm})$ in the eastern part of the site (Figure 4). Its association with a primarily non-ceramic lithic scatter in that area suggests that the archeological deposits there primarily date to the Archaic (Late Archaic?) period. It is made from a heattreated and coarse-grained quartzite. The blade has an impact fracture from its use as a projectile, and the stem has a snap fracture. It is $22 \mathrm{~mm}$ in width and $7 \mathrm{~mm}$ in thickness, with an $18 \mathrm{~mm}$ stem width.

The flake tool is a expedient end scraperside scraper (ST T-48, $0-20 \mathrm{~cm}$ ) made on a local red chert with cortical remnants. It probably was used by the prehistoric Caddoan occupants of the Harrison Bayou site to scrape animal hides, bone, and wood. The tool has a steep and $16 \mathrm{~mm}$ long used edge marked by micro-step fractures caused by the tool edge being worked on hard and durable objects. The flake tool measures $26 \times 17 \times 3 \mathrm{~mm}$ in length, width, and thickness.

A completed thin bifacial tool with wellformed and pressure-flaked bifacial edges, probably a knife, made of a heat-treated novaculite, is from ST T-48 $(20-40 \mathrm{~cm})$, apparently below the preserved midden deposits in this part of the site. The thin biface was likely broken by a snap fracture either after it was completed, or else during its use. The broken fragment measures $33 \mathrm{~mm}$ in width and $8 \mathrm{~mm}$ in thickness; the large size of this tool, compared to the typically small size of available pebbles and cobbles in the Caddo Lake bioregion, strongly suggests that this novaculite tool was manufactured outside the Caddo Lake bioregion (perhaps in southwestern Arkansas, where novaculite raw materials are abundant) and brought or traded to the site occupants. Saunders and Allen (1997:1820) have pointed out that the trade in novaculite from the Ouachita Mountains was particularly common during the Late Archaic period. 
Volume 11(3), October 2000

The one groundstone tool was a fragment of a mano or small grinding slab of ferruginous sandstone found in ST C-49 $(20-40 \mathrm{~cm} \mathrm{bs})$. This is in the far southeastern end of the Harrison Bayou site (Figure 4). Such tools are particularly abundant in Archaic and Woodland period contexts in Northeast Texas, and probably were used to grind and crush plant seeds and nut shells.

The five pieces of ferruginous sandstone fire-cracked rock $(0.5 \mathrm{~kg})$ were found in ST C-31 $(20-40 \mathrm{~cm})$ and ST T-49 $(0-20$ $\mathrm{cm})$. Their occurrence suggests that small burned rock features are present at the site in shallow Caddoan and probable Archaic archeological contexts.
Of the 131 sherds from the Harrison Bayou site, there are eight plain rim sherds (including two that may be part of a pipe bowl), 45 decorated rim and body sherds, and 78 plain sherds. The sherds are concentrated in a ca. 4000 square meter area at the western tip of the upland ridge, particularly in ST D-13, ST D-14, ST T14, ST T-15, ST T-47, ST T-48, and ST T49 (Figure 5). Because midden deposits were identified in ST T-15, ST T-47, and ST T-49, these seven excavation units clustered in a ca. $35 \times 15 \mathrm{~m}$ stretch on the ridge may be used to approximate the extent of the preserved Caddoan midden at Harrison Bayou. Three widely scattered shovel tests in the eastern part of the site also contained prehistoric grog-tempered Caddoan pottery (Figure 5), documenting

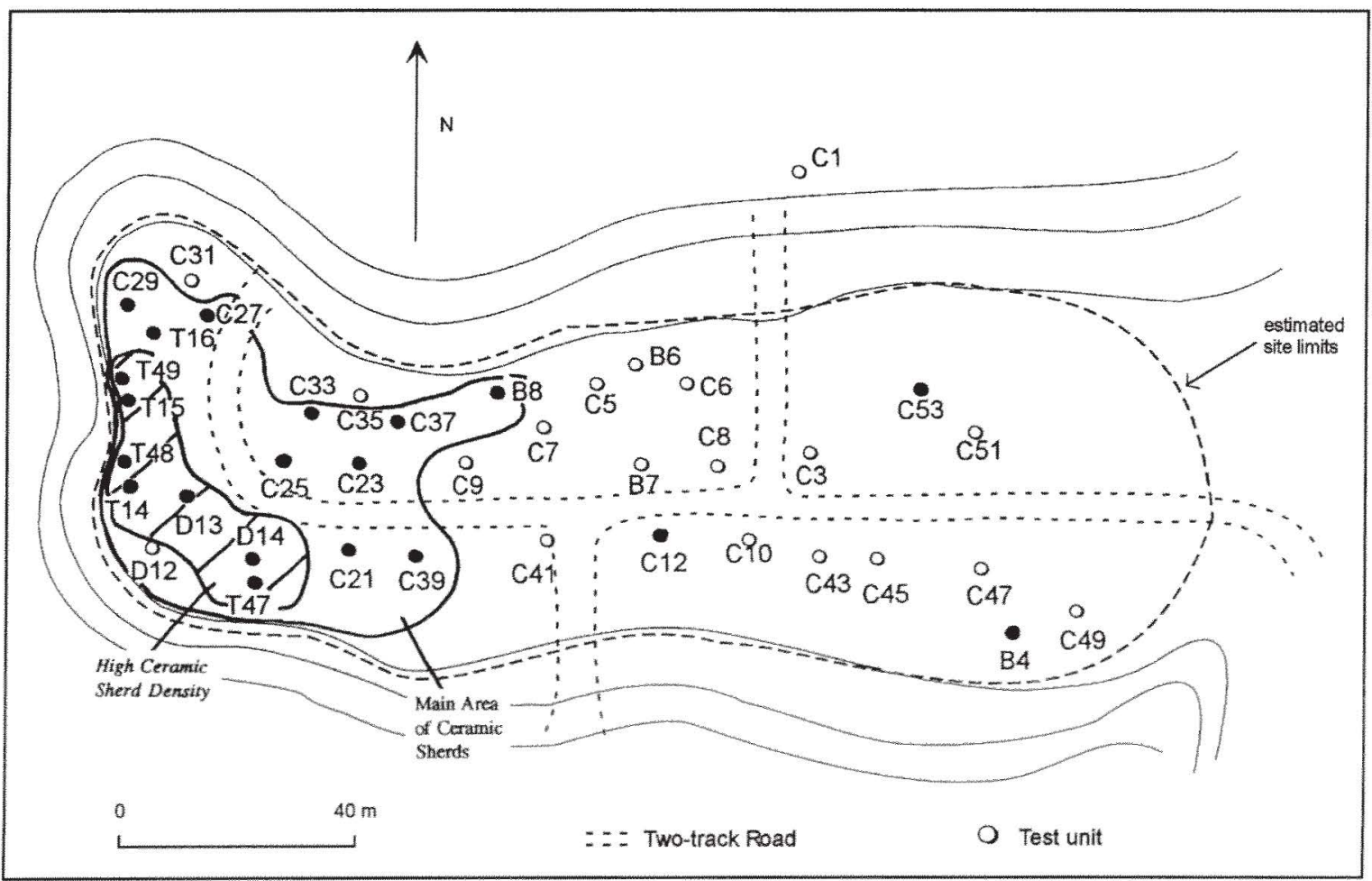

Figure 5. Distribution of Caddoan ceramics at the Harrison Bayou site. 
Caddoan pottery (Figure 5), documenting use of that part of the Harrison Bayou site in Middle Caddoan times.

Not counting the two possible bowl sherds, the plain/decorated sherd ratio is 1.87. There is an interesting temporal trend in the Caddoan ceramics from parts of the Red River valley (in northwestern Louisiana) below the Great Bend, the middle Sabine River basin, and the Neches-Angelina River basins for larger portions of vessel surfaces to be decorated, particularly with the introduction of brushing on the bodies of utility jars. Consequently, through time, ceramic assemblages have lower proportions of undecorated sherds (Girard 1996:24). Analyses of the ceramics from several different contexts in the Red, middle Sabine, and Neches-Angelina river basins in Northeast Texas and northwestern Louisiana document this trend nicely, with pre-A.D. 1200 Caddoan sites such as Festervan (16BO327), 41SY81 (Robinson 1997), and Bison (McClurkan et al. 1966) having plain/decorated sherd ratios that range between $2.97-4.80$. Thirteenth and $14^{\text {th }}$ century sites, including Vanceville (16BO7, sub-mound midden and residential areas) and Tyson (41SY92; Middlebrook 1994), have plain/decorated sherd ratios of 1.30 - 1.61. Late Caddoan sites at McGee Bend Reservoir (including Walter Bell, Etoile, and Wylie Price; Jelks 1965), Toledo Bend Reservoir (Salt Lick, Goode, and Bison, Area B; McClurkan et al. 1966; Woodall 1969), and Vanceville (on the Red River) dating between ca.
A.D. 1450 - 1650 have ratios of 0.56 1.03. If this plain/decorated sherd ratio is applicable to the Caddo Lake bioregion and we believe that it is given the ceramic and cultural affinities of the Caddoan groups along the Red River in northwestern Louisiana and in the Caddo Lake area (Thurmond 1990) - the plain/decorated sherd ratio at the Harrison Bayou site indicates the principal Caddoan component dates between the $14^{\text {th }}$ and mid- $15^{\text {th }}$ centuries.

The ceramics from the Harrison Bayou site are principally tempered with grog, grog-bone, and bone (Table 1); four of the sherds have either a fine sandy paste or no apparent temper added to the clay paste. They are from vessels that were decorated, either on the rim or on the rim and body of the vessels. With the exception of the temper classes with less than three sherds (i.e., grog-grit, grit, sandy paste, and no temper), the other temper classes are well represented by decorated sherds.

The 45 decorated sherds are dominated by parallel brushing elements, as this decoration accounts for 73 percent of the decorated sherds from the Harrison Bayou site (Table 2). Only one of the decorated sherds, a horizontal engraved rim, is from a fine ware bowl or carinated bowl; the remainder of the decorated sherds are from utility ware jars. The horizontal engraved rim (direct with an everted and folded lip) from ST T-14 $(20-40 \mathrm{~cm})$ consists of a single engraved line below the lip. 
Table 1. Ceramic Temper Classes at the Harrison Bayou Site.

\begin{tabular}{|l|r|r|r||}
\hline \multicolumn{1}{|c|}{ Temper class } & \multicolumn{1}{|c|}{$\begin{array}{c}\text { plain body } \\
\text { sherd }\end{array}$} & $\begin{array}{c}\text { plain rim } \\
\text { sherd }\end{array}$ & $\begin{array}{c}\text { decorated rim } \\
\text { and body sherds }\end{array}$ \\
\hline \hline Grog & 42 & 4 & 18 \\
\hline Grog-bone & 20 & - & 14 \\
\hline Bone & 7 & - & 10 \\
\hline Grog-Sandy Paste & 5 & 2 & 3 \\
\hline Grog-Grit & 1 & - & - \\
\hline Grit & 1 & - & - \\
\hline Sandy Paste & 1 & $2 *$ & $\mathbf{4 5}$ \\
\hline None Apparent & 1 & - & $\mathbf{8}$ \\
\hline Totals & $\mathbf{7 8}$ & & - \\
\hline
\end{tabular}

* Probable pipe bowl sherds from ST T-49 (20 - $40 \mathrm{~cm}$ bs)

Table 2. Ceramic Decorative Elements and Temper Classes.

\begin{tabular}{|l|r|r|r|r|r|r|r|r|r|r||}
\hline \hline Temper Class & PB & PB-A & HB & OB & A & I-P & DI & SLI & OLI & HE \\
\hline \hline Grog & 13 & 1 & - & - & 1 & 1 & - & 2 & - & \\
\hline Grog-Bone & 10 & - & 1 & 1 & - & - & 1 & - & - & 1 \\
\hline Bone & 8 & 1 & - & - & - & - & - & - & 1 & - \\
\hline Grog- Sandy Paste & 2 & - & - & - & - & - & - & 1 & - & - \\
\hline Grit & - & - & - & - & - & - & - & - & - & - \\
\hline Grog-Grit & - & - & - & - & - & - & - & - & - & - \\
\hline Sandy Paste & - & - & - & - & - & - & - & - & - & - \\
\hline No temper & - & - & - & - & - & - & - & - & - & -1 \\
\hline Totals & 33 & 2 & 1 & 1 & 1 & 1 & 1 & 3 & 1 & 1 \\
\hline
\end{tabular}

* $\mathrm{PB}=$ parallel brushed; $\mathrm{PB}-\mathrm{A}=$ parallel brushed-appliqued; $\mathrm{HB}=$ horizontal brushed; $\mathrm{OB}=$ opposed brushed; $\mathrm{A}=$ appliqued; $\mathrm{I}-\mathrm{P}=$ incised-punctated; $\mathrm{DI}=$ diagonal incised; $\mathrm{SLI}=$ single line incised; $\mathrm{OLI}=$ opposed line incised; $\mathrm{HE}=$ horizontal engraved 
The parallel brushed sherds are from the bodies of jars that may have had incised, brushed, and/or punctated rim decorations (i.e., Pease Brushed-Incised). The two parallel-brushed and appliqued body sherds are a common decorative variety on Pease Brushed-Incised jars, as is the horizontal brushed rim sherd from ST T$48(20-40 \mathrm{~cm})$. The one incisedpunctated rim (ST T-49, $0-20 \mathrm{~cm}$ ) has a single horizontal incised line below the lip and at least one row of tool punctations, and may also be from a Pease BrushedIncised jar. The rim is direct, with a rounded lip, and the vessel was fired in a reducing environment (cf. Teltser 1993). Another jar rim (ST T-49, $20-40 \mathrm{~cm}$ ) has a set of diagonal incised lines, while a body sherd (ST T-49, $0-20 \mathrm{~cm}$ ) has opposed incised line, probably on the vessel body. The body decoration, if any, that accompanies the diagonal incised rim is unknown. This vessel was also fired and cooled in a reducing environment.

The dominance of parallel brushed sherds, and sherds with parallel brushappliqued, diagonal incised, and opposed incised decorative elements on vessel bodies are consistent with a Caddoan ceramic assemblage that dates from ca. A.D. 1200 - 1400. Girard's (1998) seriation of Caddoan utilitarian jar forms from the Red River basin in northwestern Louisiana - not far from the Caddo Lake bioregion - indicates that the utilitarian jars made between ca. A.D. 1200 - 1400 included: 1) vessels with vertical (or parallel) brushed and appliqued bodies, and horizontal brushed or incised rims with horizontal rows of punctates, and 2) vessels with horizontal incised rims and vertical and opposed incised lines on vessel bodies. More than 84 percent of the Harrison Bayou site decorated sherds from the 1998 archeological investigations belong to the former kind of decorated utilitarian jar, and 4.5 percent of the decorated sherds likely belong with the latter utilitarian jar form.

The grog and grog-sandy paste sherds appear to be from vessels (almost exclusively utilitarian jars decorated with parallel or vertical brushing) that were fired in a similar manner, as $80-81$ percent of the sherds in these two temper classes were fired in a reducing environ-ment; half of the sherds were then cooled in a high oxygen environment (Table 3 ). Conversely, the grog-bone tempered wares have a higher percentage of sherds fired in an oxidizing environment (21 percent, compared to 8 - 10 percent among the grog and grog-sandy paste sherds), a much lower percentage of sherds from vessels fired and cooled strictly in a reducing environment, but the highest proportion of sherds (64 percent) fired in a reducing environment and cooled in a high oxygen environment. This temper class also has parallel brushed sherds among the decorated sherds, along with four types of decorative motifs not represented among the other temper classes: horizontal engraved, horizontal brushed, opposed brushing, and diagonal incised. The bone-tempered class has comparable proportions of sherds that are from vessels that were fired in oxidized, incompletely oxidized, and reduced environments (Table 3). Again, the most 
Volume 11(3), October 2000

Table 3. Temper Classes and Firing Environments.

\begin{tabular}{|l|r|r|r|r|}
\hline \multicolumn{1}{|c|}{ Temper Classes } & Oxidized & $\begin{array}{c}\text { Incompletely } \\
\text { Oxidized }\end{array}$ & Reduced & $\begin{array}{c}\text { Reduced, } \\
\text { Cooled in } \\
\text { High Oxygen }\end{array}$ \\
\hline \hline Grog - Sandy Paste & 1 & 1 & 4 & 4 \\
\hline Grog & 5 & 7 & 26 & 25 \\
\hline Grog- Bone & 7 & 2 & 3 & 22 \\
\hline Bone & 5 & 3 & 4 & 5 \\
\hline Other* & 4 & - & - & 2 \\
\hline Totals & $\mathbf{2 2}$ & $\mathbf{1 3}$ & $\mathbf{3 7}$ & $\mathbf{5 8}$ \\
\hline
\end{tabular}

* No apparent temper, grit-tempered, grog-grit-tempered, and sandy paste

common decorative element represented in the bone-tempered sherds is parallel brushed (Table 2).

The significant differences between the temper classes in firing conditions, but the similarities between them in the types of vessels being made and the kinds of decorative elements represented in the vessels, indicate that utilitarian vessels of similar design and form were being made at the Harrison Bayou site that were fired and cooled in open fires under a variety of circumstances. The wide sharing of design elements among the jars, but the technological differences between them suggest the following: a) that several different potters lived at the site, who fired vessels differently, and b) that different clay sources may have been used by these potters, and depending upon their composition and plasticity, different tempers had to be added to them to insure that sturdy and durable vessels could be successfully made and fired.

The six plain rims are from ST D-14 $(\mathrm{n}=1)$, ST T $-47(\mathrm{n}=1)$, ST T-48 $(\mathrm{n}=1)$, ST T-49 $(n=1)$, and ST C-29 $(n=2)$, all in or near the estimated Middle Caddoan midden deposits at the western end of the Harrison Bayou site (Figure 5). All have direct or vertical rim profiles, and five have rounded lips; the lip profile on the rim from ST D-14 is indeterminate. Also, one rim from ST C-29, tempered with grog, has an exterior thickened lip. The two small plain sandy paste rims from ST $\mathrm{T}-49$ are quite thin $(3.6-3.8 \mathrm{~mm})$ and were fired in a reducing environment, but cooled in a high oxygen environment. The curvature on one rim (which has a rounded lip) suggests it has a small orifice diameter, possibly the bowl to a longstemmed or elbow pipe.

Three pieces of daub and four pieces of burned clay were recovered in six shovel 
tests and/or $50 \times 50 \mathrm{~cm}$ units (Perttula and Nelson 1999:Appendix III), particularly between $0-20 \mathrm{~cm}$ bs (Figure 2). They probably represent preserved remnants of clay-plastered wall and thatch from
Caddoan structures built on the Harrison Bayou site, although the low density of these materials may indicate that the structures had not been burned down before they were abandoned.

\section{Summary}

The Harrison Bayou site is located on a high ridge along the east side of Harrison Bayou, and appears to principally contain prehistoric Caddoan midden deposits and/ or features. It has high densities (ca. 100 200 sherds per cubic meter) of Middle Caddoan ceramics that are estimated to date between ca. A.D. 1200 - 1400, mainly brushed and parallel incised sherds from cooking jars and bowls, lithic debris and tools (including contracting stem arrowpoints), burned animal bone, burned clay and daub, and small amounts of firecracked rock. All of these attributes suggest that the site is a habitation site (small hamlet and/or farmstead) with preserved Caddoan structures (houses, arbors, and ramadas), associated trash midden deposits, and outdoor cooking and heating features. This archeological site clearly has the potential to contribute new and important information on a variety of research issues developed by the Texas State Historic Preservation Office (Kenmotsu and Perttula 1993:69-187) concerning the prehistoric Caddoan settlement of the Caddo Lake bioregion. Specifically, it has the research potential to contribute important archeological information relevant to addressing many of the study units posed in the Historic Context "The Development of Agriculture in Northeast Texas Before A.D. 1600" (Perttula 1993).
Of particular significance is the presence of prehistoric Caddoan pottery in good contexts at the site, and the abundance of archeological deposits from residential contexts which should permit research focusing on "the hierarchical arrangement of community mound centers, villages, hamlets, and farmsteads in the Cypress ... basin prior to A.D. 1400" (Perttula 1993: 138). Furthermore, the material culture present at this Middle Caddoan site can directly contribute to a better understanding of the following research questions: a) ceramic indicators of Caddoan group boundaries in the Big Cypress drainage; $b$ ) the incidence of utility vessel forms and other ceramic forms from Caddoan household contexts and how this relates to the intensification of agriculture and the processing and cooking of plant foods; and c) stylistic and cultural affiliations between Caddoan groups living in the Caddo Lake bioregion and their Caddoan neighbors in the Red River basin, and the implications of these affiliations with respect to the development and internal social organization of local and regional Caddoan communities before and after ca. A.D. 1400 (Perttula 1993:140141).

Because the site has a residential occupation that would have been settled for 
Volume 11(3), October 2000

several generations, it is to be expected that, in addition to preserved house structures, the site may also contain burials from small family cemeteries. From archeological research conducted throughout Northeast Texas for a number of years (e.g., Perttula 1995, 1999), it has been well established that prehistoric Caddo residential settlements contain such features.

\section{Acknowledgments}

We would like to thank Don Henley, Dwight Shellman, Sara Kneipp, and Barbara Ornitz of the Caddo Lake Institute, Inc. for their willingness to consider cultural resources as part of their Scholar's Program, and for financially supporting the archeological investigations in the lease lands along Harrison Bayou. We also want to thank Stacey Halfmoon, Bobby Gonzalez, and Brien Haumpo of the Caddo Indian Tribe of Oklahoma for working with us during the March 1998 archeological investigations. The archeological work also could not have been accomplished without the hard work of students and teachers at Wiley College in Marshall, Texas, and Louisiana State University at Shreveport (LSUShreveport). We thank the following: from Wiley College - Raymond Fogg, Michael Pearson, Marlo Anderson, Renee Pleasant, Murline Ingram, Kenneth Alford, Bianca Knighten, Quintence Mays, Nateasel Lataye Hinton, Mavis Mahnayarare, Joe Davis, and Wesley Connor; from LSUShreveport - Alan Thompson, Chuck Lederner, Susan Kuhn, and Cynthia Morvan.

\section{References Cited}

Albertson, Paul E., and Joseph B. Dunbar 1993 Geomorphic Investigation of Shreveport to Daingerfield Navigation Project. Technical Report GL-93-31. U.S. Army Engineer Waterways Experiment Station, Geotechnical Laboratory, Vicksburg.

Brown, David E., Frank Reichenbacher, and Susan E. Franson

1998 A Classification of North American

Biotic Communities. University of Utah Press, Salt Lake City.

Cliff, Maynard B., Duane E. Peter, Floyd
B. Largent, Jr., and Philip R. Waite 1996 Longhorn Army Ammunition Plant Cultural Resources Management Plan. Geo-Marine, Inc., Plano.

Cliff, Maynard B., Steve M. Hunt, Floyd Kent, Melissa M. Green, and Duane E. Peter 1995 Archeological Survey of 1993-1994 Timber Harvesting Areas, Longhorn Army Ammunition Plant, Harrison County, Texas. Miscellaneous Report of Investigations Number 71. GeoMarine, Inc, Plano. 
Diamond, D.D., David H. Riskind, and S.L. Orzell

1987 A Framework for Plant Community Classification and Conservation in Texas. The Texas Journal of Science 39:203-221.

Ford, James A. 1936 Analysis of Indian Village Site Collections from Louisiana and Mississippi. Anthropological Study No. 2. Department of Conservation, Louisiana Geological Survey, Baton Rouge.

Gadus, E. Frances, Martha Doty Freeman, and Ross C. Fields

1998 Archeological Survey of 319 Hectares at the Longhorn Army Ammunition Plant, Harrison County, Texas. Reports of Investigations No. 119. Prewitt and Associates, Inc., Austin.

Gibson, Jon L.

1970 Archaeological Survey at Caddo Lake, Louisiana and Texas. Contributions in Anthropology, Number 6. Department of Anthropology, Southern Methodist University, Dallas.

Girard, Jeffrey S.

1996 Regional Archaeology Program, Management Unit 1, Seventh Annual Report. Northwestern State University, Natchitoches, Louisiana.

1998 Ceramic Seriation and the Spatial Development of a Prehistoric Caddoan Community in Northwest Louisiana. Paper presented at the $40^{\text {th }}$ Caddo
Conference, Arkadelphia, Arkansas.

Golden, Michael L., Alan C. Peer, and Samuel E. Brown, Jr.

1994 Soil Survey of Harrison County,

Texas. United States Department of Agriculture, Soil Conservation Service, Washington, D.C.

Hardy, Laurence M.

1995 Checklist of the Amphibians and Reptiles of the Caddo Lake Watershed in Texas and Louisiana. Bulletin of the Museum of Life Sciences No. 10. Museum of Life Sciences, Louisiana State University in Shreveport, Shreveport.

Ingold, James L.

1995 Checklist of the Birds of the Caddo Lake Watershed in Texas and Louisiana. Bulletin of the Museum of Life Science No. 11. Louisiana State University in Shreveport, Shreveport.

Ingold, James L., and Laurence M. Hardy 1996 Web of Life: The Ecology and Biodiversity of Caddo Lake. Louisiana State University in Shreveport, Shreveport.

Jelks, Edward B.

1965 The Archeology of McGee Bend Reservoir, Texas. Ph.D. dissertation, Department of Anthropology, The University of Texas at Austin.

Kenmotsu, Nancy A., and Timothy K. Perttula (editors)

1993 Archeology in the Eastern Planning

Region, Texas: A Planning Document. Cultural Resource Management 
Volume 11(3), October 2000

Report 3. Texas Historical Commission, Department of Antiquities Protection, Austin.

McClurkan, Burney B., William T. Field, and J. Ned Woodall

1966 Excavations in Toledo Bend Reservoir, 1964-85. Papers of the Texas Archeological Salvage Project, No. 8. Texas Archeological Salvage Project, The University of Texas at Austin.

Middlebrook, Tom

1994 An Update of Archaeological Investigations at the Tyson Site (41SY92). Journal of Northeast Texas Archaeology 3:1-36.

Pearson, Charles E., Jacques Bagur, and James Duff

1994 Identification and Analysis of Historic Watercraft in the Shreveport, Louisiana, to Daingerfield, Texas, Navigation Project. Coastal Environments, Inc., Baton Rouge.

Perttula, Timothy K.

1993 The Development of Agriculture in Northeast Texas Before A.D. 1600. In: Archeology in the Eastern Planning Region, Texas: A Planning Document, edited by Nancy A. Kenmotsu and Timothy K. Perttula, pp. 121-146. Cultural Resource Management Report 3. Texas Historical Commission, Department of Antiquities Protection, Austin.

1995 The Archeology of the Pineywoods and Post Oak Savanna of Northeast
Texas. Bulletin of the Texas Archeological Society 66:331-359.

1999 The Prehistoric and Caddoan Archeology of the Pineywoods and Post Oak Savanna of Northeast Texas. In: The Prehistoric Archeology of Texas, edited by Timothy K. Perttula. Ms. under review by Texas A\&M University Press, College Station.

Perttula, Timothy K., and Bo Nelson 1999 An Archeological Survey of Harrison Bayou Lease Lands at the Longhorn Army Ammunition Plant, Harrison County, Texas. Report of Investigations No. 12. Archeological and Environmental Consultants, Austin.

Peter, Duane E., and Cynthia StilesHanson

1990 An Assessment of the Cultural Resources Within the Longhorn Army Ammunition Plant, Harrison County, Texas. Miscellaneous Report of Investigations No. 3. Geo-Marine, Inc., Plano.

Robinson, David G.

1997 Cultural Resource Investigations at the Ducks Unlimited Marsh (DUM) Project, North Toledo Bend Reservoir; Shelby County, Texas. Report 97-3. Cultural Resource Program, Texas Parks and Wildlife Department, Austin.

Roemer, Erwin, and Jay R. Newman 1988 A Cultural Resources Survey of Proposed Actions Related to Test Area Expansion, LHAAP, Harrison County, 
Texas. U.S. Army Corps of Engineers, Fort Worth District, Fort Worth.

Saunders, Joe, and Thurman Allen 1997 The Archaic Period. Louisiana Archaeology 22:1-30.

Sheffield, William J. 1995 A Summer-Fall Ecological Reconnaissance of the Big Cypress Bayou Watershed, Texas and Louisiana. Texas Parks and Wildlife Department, Austin.

Story, Dee Ann

1990 Culture History of the Native Americans. In: The Archeology and Bioarcheology of the Gulf Coastal Plain, by Dee Ann Story, Janice A. Guy, Barbara A. Burnett, Jerome C. Rose, Martha D. Freeman, D. Gentry Steele, Karl J. Reinhard, and Ben W. Olive, pp. 163-366. 2 Vols. Research Series No. 38. Arkansas Archeological Survey, Fayetteville.

Teltser, Patrice A.

1993 An Analytic Strategy for Studying Asemblage-Scale Ceramic Variation: A Case Study from Southeast Missouri. American Antiquity 58(3): $530-543$.

Thurmond, J. Peter 1990 Archeology of the Cypress Creek
Drainage Basin, Northeast Texas and Northwestern Louisiana. Studies in Archeology 5. Texas Archeological Research Laboratory, The University of Texas at Austin.

U.S. Department of the Interior, General Land Office 1914 Examination of Ferry (Caddo) Lake. 3 Vols. U.S. Department of the Interior, Supervisory of Surveys, Commissioner of the General Land Office, Washington, D.C.

Van Duyne, Cornelius, and W.C. Byers 1913 Soil Survey of Harrison County, Texas. U.S. Department of Agriculture, Bureau of Soils. Government Printing Office, Washington, D.C.

Webb, Clarence $\mathrm{H}$.

1948 Caddoan Prehistory: The Bossier Focus. Bulletin of the Texas Archeological and Paleontological Society 19:100-147.

Woodall, J. Ned

1969 Archaeological Excavations in the Toledo Bend Reservoir, 1966. Contributions in Anthropology No. 3. Department of Anthropology, Southern Methodist University, Dallas. 